\title{
Adenovirus-mediated Transfer of a Gene Encoding Cholesterol $7 \alpha$-Hydroxylase into Hamsters Increases Hepatic Enzyme Activity and Reduces Plasma Total and Low Density Lipoprotein Cholesterol
}

\author{
David K. Spady, Jennifer A. Cuthbert, Maureen N. Willard, and Robert S. Meidell \\ Department of Internal Medicine, Divisions of Gastroenterology, Hepatology, and Cardiology, and the Ryburn Cardiology Center, \\ University of Texas Southwestern Medical Center, Dallas, Texas 75235
}

\begin{abstract}
Clinical interventions that accelerate conversion of cholesterol to bile acids reduce circulating low density lipoprotein (LDL) cholesterol concentrations. The initial and rate-limiting step in the bile acid biosynthetic pathway is catalyzed by hepatic cholesterol $7 \alpha$-hydroxylase. To examine the effects of transient primary overexpression of this enzyme on sterol metabolism and lipoprotein transport, we constructed a recombinant adenovirus in which a cDNA encoding rat $7 \alpha$-hydroxylase is expressed from the human cytomegalovirus immediate-early promoter (AdCMV7a). Syrian hamsters administered AdCMV7 $\alpha$ intravenously accumulated transgene-specific mRNA in the liver and demonstrated a dose-dependent increase in hepatic microsomal $7 \alpha$-hydroxylase activity. The increased conversion of cholesterol to bile acids resulted in a compensatory increase in hepatic cholesterol synthesis. In addition, overexpression of $7 \alpha$-hydroxylase reduced the rate of LDL cholesterol entry into the plasma space and, in animals maintained on a Westerntype diet, restored hepatic LDL receptor expression. As a consequence, plasma LDL concentrations fell by $\sim 60 \%$ in animals maintained on control diet and by $\sim 75 \%$ in animals consuming a Western-type diet. Plasma high density lipoprotein cholesterol levels were reduced to a lesser degree. These results demonstrate that transient upregulation of bile acid synthesis by direct transfer of a $7 \alpha$-hydroxylase gene favorably alters circulating lipoprotein profiles and suggest one potential molecular target for genetic strategies aimed at reducing cardiovascular risk. (J. Clin. Invest. 1995. 96:700-709.) Key words: bile acids • cholesterol • genes • viruses • lipoprotein
\end{abstract}

\section{Introduction}

An elevated concentration of low density lipoprotein (LDL) in plasma is an important risk factor for the development and progression of atherosclerotic cardiovascular disease (1). The

This study was presented in part at the American Heart Association Meetings in Dallas on 14 November 1994.

Address correspondence to Robert S. Meidell, M.D., Division of Cardiology, University of Texas Southwestern Medical Center, NB11.106a, 6000 Harry Hines Blvd., Dallas, Texas 75235-8573. Phone: 214-648-1421; FAX: 214-648-1450; E-mail: bmeidell@cardiology.pmh.swmed.edu.

Received for publication 7 December 1994 and accepted in revised form 21 April 1995.

J. Clin. Invest.

(C) The American Society for Clinical Investigation, Inc. $0021-9738 / 95 / 08 / 0700 / 10 \quad \$ 2.00$

Volume 96, August 1995, 700-709 liver plays a central role both in the regulation of plasma LDL concentrations and in the maintenance of whole body sterol balance (2). Absorbed dietary cholesterol is transported to the liver in chylomicron remnants, and secretion of cholesterol into bile, either directly or after conversion to bile acids, is the only significant mechanism whereby cholesterol is removed from the body. In response to changes in cholesterol influx or efflux, the liver compensates by adjusting the rate of de novo cholesterol synthesis and, in some cases, the rate of receptor-dependent LDL uptake. Since the liver is the principal site of LDL catabolism, changes in hepatic LDL receptor activity generally produce reciprocal changes in circulating LDL concentrations.

Conversion of cholesterol to bile acids is the major regulated pathway whereby cholesterol is eliminated from the body. The first and rate-limiting step in the bile acid biosynthetic pathway is catalyzed by cholesterol $7 \alpha$-hydroxylase (3). While the mechanisms have not been completely defined, $7 \alpha$-hydroxylase activity appears to be regulated principally at the level of gene expression in response to bile acids fluxing through the liver in the enterohepatic circulation $(4,5)$. Bile acid sequestrants such as cholestyramine bind bile acids in the intestinal lumen, thereby preventing their reabsorption. Loss of bile acids from the enterohepatic circulation results in derepression of $7 \alpha$-hydroxylase expression (6-10) and an increase in the rate of bile acid synthesis $(9,11)$. The liver compensates for the accelerated loss of cholesterol by increasing the rate of de novo cholesterol synthesis and, if this is inadequate, by increasing the receptordependent uptake of LDL from plasma (10), thereby lowering circulating LDL levels. Clinical interventions that interfere with the enterohepatic cycling of bile acids have been shown to reduce the risk of myocardial infarction and cardiovascular mortality $(12,13)$. Unfortunately, tolerated doses of bile acid sequestrants have a relatively limited capacity to increase hepatic $7 \alpha$-hydroxylase expression and, as a consequence, often have only modest cholesterol lowering activity.

These observations suggest that primary overexpression of a $7 \alpha$-hydroxylase gene might exert a salutary effect on whole body sterol balance and on circulating LDL cholesterol levels. We (14) and others (15-18) have observed previously that intravenous administration of recombinant adenovirus to animals is associated with preferential infection of the liver, and that adenovirus-mediated transfer of genes encoding apolipoprotein A-1 (14) and the LDL receptor (15-17) results in transient overexpression of these proteins, producing significant alterations in circulating lipoprotein profiles. The current studies were undertaken to determine whether adenovirus-mediated transfer of a gene encoding $7 \alpha$-hydroxylase would increase hepatic enzyme activity and bile acid synthesis and to examine the effects of primary overexpression of $7 \alpha$-hydroxylase on lipoprotein metabolism in vivo. These studies show that infection of hamsters with a recombinant adenovirus encoding cholesterol $7 \alpha$-hydroxylase transiently increases hepatic micro- 
somal $7 \alpha$-hydroxylase activity and produces a dose-dependent reduction in plasma total, LDL, and, to a lesser degree, HDL cholesterol levels, despite suppression of endogenous $7 \alpha$-hydroxylase gene expression and a compensatory increase in de novo cholesterol synthesis by the liver.

\section{Methods}

Recombinant viruses. The recombinant adenovirus AdCMV7 $\alpha$ was generated by homologous recombination in 293 cells (19) essentially as described previously (14). A cDNA encoding rat $7 \alpha$-hydroxylase (generously provided by Dr. David Russell at this institution) was inserted into pACCMVpLpA (20), and the resulting plasmid $(10 \mu \mathrm{g})$ was cotransfected into 293 cells with $5 \mu \mathrm{g}$ of Xbal-digested AdSVtPA (a derivative of Addl309 carrying a human tissue plasminogen activator cDNA expressed from the SV40 early promoter) DNA by calcium phosphate coprecipitation using a glycerol shock to boost transfection efficiency. Homologous recombination between the pAC plasmid and the right $91 \%$ fragment of the viral genome resulted in the formation of a recombinant viral genome of packageable size in which the CMV7 $\alpha$ fusion gene replaces the native adenovirus early region 1 .

Clonally derived recombinant viruses were isolated and propagated as described previously (14) and characterized by restriction analysis and Southern blotting of viral DNA prepared from productively infected 293 cells. Generation of the recombinant adenoviruses AdRR5, which lacks an inserted gene in the E1 position, AdCMVLuc, carrying a gene encoding firefly luciferase, and AdCMV $\beta$ gal, carrying a gene encoding a nuclear-localizing variant of Escherichia coli $\beta$-galactosidase, have been described elsewhere (15).

Large scale production of recombinant adenovirus was performed as described previously (21) by infecting confluent monolayers of 293 cells grown in $15-\mathrm{cm}$ tissue culture plates with primary stock at a multiplicity of infection of 0.1-1.0. Infected monolayers were lysed with NP40 (final concentration $0.1 \%$ ) when $>90 \%$ of the cells showed cytopathic changes, and recombinant virus was purified by precipitation with polyethylene glycol 8000 , centrifugation on a discontinuous $\rho$ $=1.3 \mathrm{grams} / \mathrm{ml}-\rho=1.4 \mathrm{grams} / \mathrm{ml} \mathrm{CsCl}$ density gradient, and desalting by chromatography on Sepharose CLAB in an isotonic saline buffer (10 mM Tris-HCl, pH 7.4, $137 \mathrm{mM} \mathrm{NaCl}, 5 \mathrm{mM} \mathrm{KCl}, 1 \mathrm{mM}$ $\mathrm{MgCl}_{2}$ ). Purified virus eluting in the void volume was collected and, after addition of sterile bovine serum albumin to a final concentration of $0.1 \mathrm{mg} / \mathrm{ml}$, snap frozen in liquid $\mathrm{N}_{2}$ and stored at $-80^{\circ} \mathrm{C}$ until used. The titer of infectious viral particles in purified stocks was determined by plaque assay in monolayers of 293 cells (19) and was routinely $>10^{10}$ plaque forming units (pfu $)^{1} / \mathrm{ml}$.

Animals and diets. All procedures involving experimental animals were performed in accordance with National Institutes of Health guidelines and under protocols approved by the Institutional Animal Care and Research Advisory Committee. Male Golden Syrian hamsters (Sasco, Inc., Omaha, NE) were housed in colony cages and subjected to light cycling. Animals were maintained on commercial rodent diet (ground Wayne Lab Blox; Allied Mills, Chicago, IL). This diet contains small amounts of cholesterol $(0.23 \mathrm{mg} / \mathrm{gram})$ and triglyceride $(50 \mathrm{mg} /$ gram). For some experiments, this control diet was supplemented with triglyceride ( $100 \mathrm{mg} / \mathrm{gram}$ coconut oil and $50 \mathrm{mg} / \mathrm{gram}$ safflower oil) and cholesterol (1 mg/gram). In addition, for some experiments, the diets were supplemented with $1 \%$ (by weight) cholestyramine. Diets were fed ad libitum and all experiments were carried out during the mid-dark phase of the light cycle.

For administration of virus, animals were lightly anesthetized with diethyl ether, a femoral vein was exposed, and $0.5-1.5 \mathrm{ml}$ of isotonic saline containing purified recombinant adenovirus was injected intravenously using a tuberculin syringe under direct visualization. Hemostasis was obtained by direct pressure, and the incision was closed with 3-0

1. Abbreviations used in this paper: HMG CoA, 3-hydroxy-3-methylglutaryl coenzyme A; pfu, plaque forming units. silk. Animals were allowed to recover on a warming tray before being returned to cages where they were provided with food and water ad libitum.

148 animals were studied in this series of experiments, of which 84 were studied while being maintained on the chow diet as follows: control $(n=30)$; infected with an irrelevant virus (AdCMVLuc or AdCMV $\beta$ gal: $n=12)$; infected with AdCMV7 $\alpha\left(2 \times 10^{9}\right.$ pfu: $n=5,1$ $\times 10^{10}$ pfu: $n=18,2 \times 10^{10}$ pfu: $n=6$ ); treated with cholestyramine $(n=9)$; and treated with both AdCMV7 $\alpha$ and cholestyramine ( $n$ $=4)$. An additional 46 animals were studied after feeding a diet supplemented with triglyceride and cholesterol (Western-type diet) as follows: supplemented diet control $(n=12)$; treated with cholestyramine $(n$ $=12)$; infected with an irrelevant virus $(n=6)$; infected with AdCMV7 $\alpha(n=12)$; and treated with both cholestyramine and AdCMV7 $\alpha$ $(n=4)$. In addition, 12 animals were studied on a diet supplemented with triglyceride alone and 6 animals were studied after $3 \mathrm{~d}$ of food restriction.

In preliminary experiments, we observed that the effects of adenovirus-mediated transfer of a $7 \alpha$-hydroxylase gene on enzyme activity and plasma cholesterol levels peaked 3-5 d after infection and began to decline within $7 \mathrm{~d}$. Consequently, subsequent studies were performed in animals $3 \mathrm{~d}$ after infection with recombinant virus.

Determination of hepatic $7 \alpha$-hydroxylase activity. Hepatic $7 \alpha$-hydroxylase activity was measured using an HPLC-spectrophotometric assay that quantifies the mass of $7 \alpha$-hydroxycholesterol formed from endogenous microsomal cholesterol after enzymatic conversion to $7 \alpha$ hydroxy-4-cholesten-3-one using cholesterol oxidase as described previously (22).

Determination of $L D L$ uptake rates in vivo. Plasma was obtained from normocholesterolemic hamsters maintained on standard rodent chow (Wayne Lab-Blox) and from normocholesterolemic human donors. The LDL was isolated from plasma by preparative ultracentrifugation in the density range of $1.020-1.055$ grams $/ \mathrm{ml}$. LDL was labeled with ${ }^{125} \mathrm{I}$ - or ${ }^{131} \mathrm{I}$-tyramine cellobiose as described previously (23). The human LDL was also reductively methylated to completely eliminate its recognition by the LDL receptor (24). Total LDL uptake into each tissue was measured using homologous (normocholesterolemic hamster) LDL, and the receptor-independent component was determined using methylated human LDL. Receptor-dependent LDL uptake was taken as the difference between total and receptor-independent uptake. Rates of hepatic LDL uptake were measured using primed infusions of ${ }^{125}$ I-tyramine cellobiose-labeled LDL. The infusions were continued for $4 \mathrm{~h}$ at which time each animal was administered a bolus of ${ }^{131} \mathrm{I}$ tyramine cellobiose-labeled LDL as a volume marker and killed 10 min later by exsanguination through the abdominal aorta. Tissue samples along with aliquots of plasma were assayed for radioactivity in a gamma counter (Packard Instrument Co., Downers Grove, IL). The amount of labeled LDL in the various tissues at $10 \mathrm{~min}{ }^{131} \mathrm{I}$ disintegrations per minute per gram of tissue divided by the specific activity of ${ }^{131} I$ in plasma) and at $4 \mathrm{~h}$ ( ${ }^{125} \mathrm{I}$ disintegrations per minute per gram of tissue divided by the specific activity of ${ }^{125} \mathrm{I}$ in plasma) was then calculated. The increase in the tissue content of LDL cholesterol or LDL protein with time represents the rate of LDL uptake in micrograms of LDL cholesterol or LDL protein per hour per gram of tissue. Changes in hepatic receptor-dependent LDL uptake (defined as the rate of receptordependent LDL uptake in an experimental animal relative to the rate of receptor-dependent LDL uptake seen in control animals at the same plasma LDL concentration) were determined as described previously $(10,25)$. The rate of LDL cholesterol entry into the plasma space (total LDL cholesterol transport) was determined as described previously $(10,25)$.

Determination of hepatic cholesterol synthesis rates. Rates of hepatic cholesterol synthesis were measured in vivo using $\left[{ }^{3} \mathrm{H}\right]$ water. As described previously (26), animals were administered $\sim 100 \mathrm{mCi}$ of $\left[{ }^{3} \mathrm{H}\right]$ water intravenously and then returned to individual cages under a fume hood. $1 \mathrm{~h}$ after the injection of $\left[{ }^{3} \mathrm{H}\right]$ water, the animals were anesthetized and exsanguinated through the abdominal aorta. Aliquots of plasma were taken for the determination of body water specific activity, and samples of liver were taken for the isolation of digitonin- 
precipitable sterols. Rates of sterol synthesis are expressed as the nanomoles of $\left[{ }^{3} \mathrm{H}\right]$ water incorporated into digitonin-precipitable sterols per hour per gram of liver or per whole organ.

Determination of mRNA levels. Hepatic $7 \alpha$-hydroxylase, LDL receptor, 3-hydroxy-3-methylglutaryl coenzyme A (HMG CoA) reductase and glyceraldehyde-3-phosphate dehydrogenase mRNA levels were determined by nuclease protection as described previously $(10,27,28)$. Samples of hamster liver were homogenized in guanidinium isothiocyanate and RNA isolated by the method of Chomczynski and Sacchi (29). Total RNA ( $40 \mu \mathrm{g})$ was hybridized with the ${ }^{32} \mathrm{P}$-labeled cDNA probes simultaneously at $48^{\circ} \mathrm{C}$ overnight. Unhybridized probe, present in excess relative to the amount of specific mRNA, was then digested with $20 \mathrm{U}$ of Mung bean nuclease (GIBCO-BRL, Gaithersburg, MD). The mRNAprotected ${ }^{32} \mathrm{P}$-labeled probes were separated on $7 \mathrm{M}$ urea, $6 \%$ polyacrylamide gels together with ${ }^{32} \mathrm{P}$-labeled MspI-digested pBR322 size standards. The radioactivity in each band, corrected for background radioactivity, was determined using an isotopic imaging system (Ambis, Inc., San Diego, CA).

Species-specific single-stranded ${ }^{32} \mathrm{P}$-labeled probes for $7 \alpha$-hydroxylase were synthesized by oligonucleotide primed synthesis from M13 subclones as described previously $(10,28,30)$. The rat probe was prepared from a subclone of a BamHI-Xbal fragment of the rat $7 \alpha$ hydroxylase cDNA spanning nucleotides 1216-1468. The template cDNA fragment for the hamster specific probe was obtained by reverse transcription-PCR using hamster liver RNA and oligonucleotide primers that span nucleotides 337-577 as described (10). Within these regions, the rat and hamster cDNA sequences differ at 35/252 and 17/ 240 nucleotides, respectively. Probes for HMG CoA reductase and the LDL receptor were prepared as described previously $(10,28)$.

Determination of bile acid pool size and composition. The liver, gallbladder, and small intestine were harvested en block from control and AdCMV7 $\alpha$-infected hamsters, placed in a 400 -ml beaker with $\sim 200 \mathrm{ml}$ ethanol (and trace amounts of $\left[24-{ }^{14} \mathrm{C}\right]$ taurocholic acid as a recovery standard), and refluxed for $4 \mathrm{~h}$. After extraction with diethyl ether, bile acids in the ethanolic extract were separated and quantified by HPLC.

Determination of liver and plasma cholesterol. Hepatic cholesterol was quantified by capillary gas-liquid chromatography. Microsomal unesterified cholesterol was quantified by HPLC. The cholesterol content of plasma was determined using an enzymatic assay kit (Boehringer Mannheim Corp., Indianapolis, IN). Cholesterol distribution in plasma was determined by gel filtration chromatography using a Superose- 6 column (Sigma Chemical Co., St. Louis, MO) as described previously (10). Equal amounts of plasma were pooled from identically treated control or treated animals and applied to the column; 2-ml aliquots were collected and assayed for cholesterol using the enzymatic assay.

Data analysis. Because of the large quantities required, several batches of recombinant viruses were used in these experiments. The data presented in each case reflect results from animals treated with a single virus stock. Data obtained from repeated experiments in which animals were treated similarly but with different batches of virus, or instrumented at different times, were not pooled for statistical analysis. Data are presented as mean $\pm 1 \mathrm{SD}$. Differences between treatments were examined using ANOVA and the Scheffe post-hoc test (31), with $P<$ 0.05 considered significant.

\section{Results}

To determine whether animals infected with a recombinant adenovirus encoding cholesterol $7 \alpha$-hydroxylase would express the transgene in liver, Syrian hamsters were administered 1 or 2 $\times 10^{10}$ pfu of control virus or AdCMV7 $\alpha$ by intravenous injection. Total RNA was prepared from livers harvested $3 \mathrm{~d}$ after infection and assayed for $7 \alpha$-hydroxylase mRNA in a nuclease protection assay using ${ }^{32} \mathrm{P}$-labeled cDNA probes specific for hamster or rat $7 \alpha$-hydroxylase. Fig. 1 illustrates expression of mRNAs encoding the endogenous and transduced $7 \alpha$-hydroxylase genes in hamsters infected with control virus or AdCMV7 $\alpha$

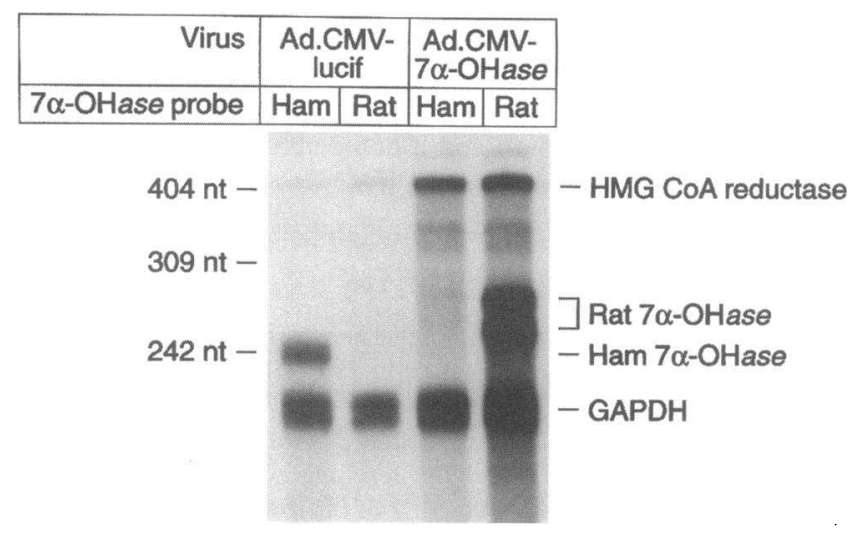

Figure 1. Nuclease protection analysis of cholesterol $7 \alpha$-hydroxylase expression in hamsters infected with AdCMV7 $\alpha$ or control virus. Hepatic RNA was prepared from hamsters $3 \mathrm{~d}$ after the intravenous injection of $1 \times 10^{10} \mathrm{pfu}$ of AdCMV7 $\alpha$ or control virus (Ad.CMV-lucif). Total RNA ( $40 \mu \mathrm{g}$ ) was hybridized with ${ }^{32} \mathrm{P}$-labeled single-stranded cDNA probes encoding hamster HMG CoA reductase, hamster glyceraldehyde-3-phosphate dehydrogenase, and either hamster or rat $7 \alpha$-hydroxylase. Fragments protected from Mung bean nuclease digestion were separated by denaturing polyacrylamide gel electrophoresis and autoradiographed.

$\left(1 \times 10^{10} \mathrm{pfu}\right)$. In this assay, the RNA-protected hamster $7 \alpha$ hydroxylase probe is 240 nucleotides. The RNA-protected rat probe is 252 nucleotides and migrates as a doublet, as observed previously in assays using native rat liver RNA to protect this probe (30).

RNA isolated from hamsters infected with control virus protected the hamster-specific $7 \alpha$-hydroxylase probe but did not protect the rat-specific $7 \alpha$-hydroxylase probe, which contains 35 nucleotide mismatches compared with the corresponding region of the hamster cDNA. In contrast, RNA purified from the livers of hamsters infected with recombinant virus encoding rat $7 \boldsymbol{\alpha}$-hydroxylase expressed transgene (rat)-specific mRNA (reflected in protection of the rat probe in a pattern identical to that observed previously using native rat liver RNA), while expression of mRNA from the native (hamster) gene was suppressed. Based on the length and specific activity of the hamster and rat probes, it could be estimated that administration of 1 $\times 10^{10}$ pfu resulted in the accumulation of $\sim 10-15$-fold higher overall levels of $7 \alpha$-hydroxylase mRNA in animals infected with AdCMV7 $\alpha$ when compared with either animals infected with control virus or uninfected animals. Infection of animals with smaller quantities of AdCMV7 $\alpha$ produced less expression of transgene-specific mRNA, and in a reciprocal manner, less suppression of the endogenous hamster gene (data not shown).

The increase in $7 \alpha$-hydroxylase mRNA observed in animals treated with AdCMV7 $\alpha$ was associated with a dose-dependent increase in hepatic microsomal $7 \alpha$-hydroxylase activity, as shown in Fig. 2. Animals infected with $2 \times 10^{9}$ pfu demonstrated marginally increased activity (2-3-fold), while infection with 1 and $2 \times 10^{10}$ pfu increased formation of $7 \alpha$-hydroxycholesterol $\sim 8$ - and 15-fold, respectively, when compared with uninfected control animals or animals infected with a recombinant adenovirus encoding firefly luciferase (AdCMVLuc). In general, the increase in $7 \alpha$-hydroxylase enzyme activity paralleled accumulation of transgene-specific mRNA.

As also shown in Fig. 2 , changes in hepatic $7 \alpha$-hydroxylase activity were accompanied by reciprocal changes in plasma 


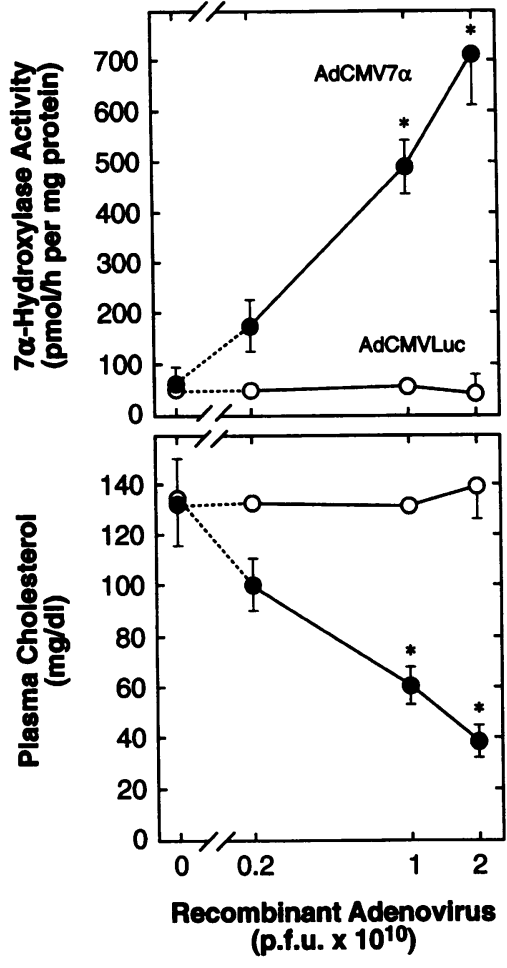

Figure 2. Hepatic microsomal $7 \alpha$-hydroxylase activity and total plasma cholesterol in hamsters administered AdCMV7 $\alpha$ or control virus. Animals were killed $3 \mathrm{~d}$ after intravenous injection of AdCMV7 $\alpha$ or control virus (AdCMVLuc). Hepatic $7 \alpha$-hydroxylase activity was measured using endogenous microsomal cholesterol as substrate. Each solid circle represents the mean \pm 1 SD for data obtained in three animals administered Ad-

CMV7 $\alpha$. Each open circle represents the mean value for data obtained in two to three animals administered control virus. * Significantly differs from the corresponding control group, $P<0.05$.

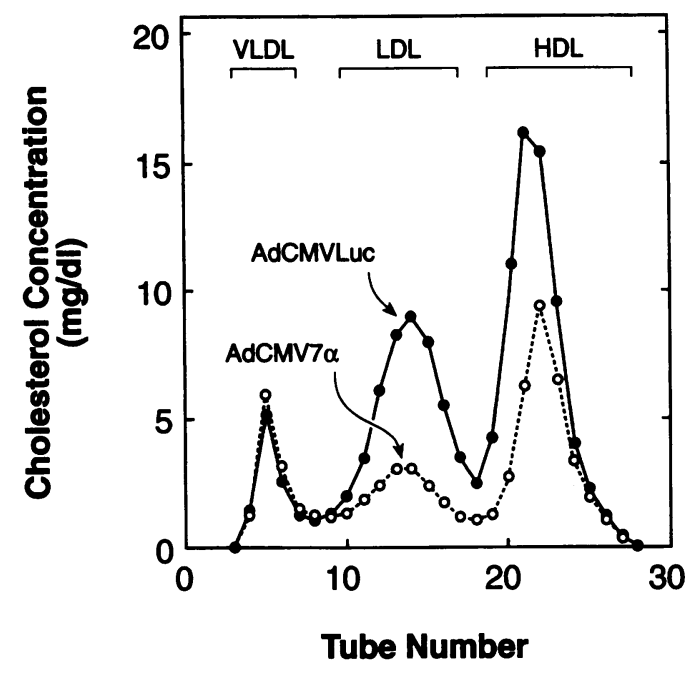

Figure 3. Effect of $7 \alpha$-hydroxylase gene transfer on the lipoprotein distribution of plasma cholesterol. Plasma samples were obtained from hamsters $3 \mathrm{~d}$ after intravenous injection of $1 \times 10^{10} \mathrm{pfu}$ AdCMV7 $\alpha$ or AdCMVLuc. Equal aliquots of plasma were pooled from three identically treated animals in each group. Pooled plasma was fractionated by Superose- 6 chromatography, and the cholesterol content of eluted fractions was determined as described in Methods. The retention times for hamster VLDL $(d<1.006$ grams $/ \mathrm{ml})$, LDL $(d=1.020-1.055$ grams $/$ $\mathrm{ml})$, and HDL $(d=1.063-1.21 \mathrm{grams} / \mathrm{ml})$ are indicated. cholesterol concentrations. Total plasma cholesterol levels fell from $131 \mathrm{mg} / \mathrm{dl}$ in uninfected control animals to $\sim 40 \mathrm{mg} / \mathrm{dl}$ in animals infected with $2 \times 10^{10} \mathrm{pfu}$ AdCMV7 $\alpha$. In contrast, total plasma cholesterol levels remained unchanged in animals administered control virus over the same dose range. In these experiments, a strong inverse correlation was observed between plasma cholesterol levels and hepatic microsomal $7 \alpha$-hydroxylase activity $\left(r^{2}=0.67, P<0.001\right)$.

Occasional animals (2/6) infected with the highest dose of virus demonstrated poor food consumption and some weight loss over the 3-4 d after infection. Data from animals that lost $>2 \%$ (3-4 grams) body weight were excluded, and subsequent experiments were performed using $1 \times 10^{10} \mathrm{pfu}$, a dose not associated with changes in food consumption or body weight. Nevertheless, a group of uninfected control animals was fasted for a similar period to exclude the possibility that partial fasting was responsible for the observed effect on plasma cholesterol levels. The fasted control animals lost $>10 \%$ of their body weight; however, plasma cholesterol fell by only $12 \%$ and hepatic $7 \alpha$-hydroxylase activity and mRNA fell by 22 and $20 \%$, respectively. To exclude a nonspecific effect of adenovirus infection, additional control animals were infected with 1-2 $\times 10^{10}$ pfu of AdCMVLuc or AdCMV $\beta$ gal. Plasma cholesterol levels $3 \mathrm{~d}$ after infection in these animals were slightly elevated (not statistically significant) compared with uninfected control animals, consistent with our prior observations in mice that infection with recombinant adenovirus per se does not significantly alter total plasma cholesterol levels (14).

The large decrease in total plasma cholesterol observed in AdCMV7 $\alpha$-infected animals reflected reductions in cholesterol carried in both the LDL and HDL fractions. Fig. 3 shows the distribution of cholesterol in individual lipoproteins, as separated by Superose- 6 chromatography, in animals infected with $1 \times 10^{10}$ pfu AdCMV7 $\alpha$ or control virus. $3 \mathrm{~d}$ after virus administration, LDL cholesterol was reduced $\sim 60 \%$ in animals in- fected with AdCMV7 $\alpha$ compared with animals infected with control virus. HDL cholesterol levels were also reduced in animals infected with AdCMV7 $\alpha$, but to a lesser degree. Compared with uninfected controls, infection with control virus (AdCMVLuc) had no effect or slightly increased LDL and HDL cholesterol levels.

Since LDL is the principal atherogenic lipoprotein in plasma, studies were carried out to investigate the mechanisms responsible for its decline. The concentration of LDL cholesterol in plasma is determined by the rate at which LDL cholesterol enters the plasma space (total LDL cholesterol transport), relative to the rate at which $\mathrm{LDL}$ cholesterol is removed from plasma, primarily by receptor-mediated clearance of LDL particles in the liver. Rates of LDL cholesterol entry into plasma (total LDL cholesterol transport) and hepatic receptor-dependent LDL uptake were determined $3 \mathrm{~d}$ after infection with 1 $\times 10^{10}$ pfu AdCMV7 $\alpha$. As shown in Fig. 4, overexpression of hepatic $7 \alpha$-hydroxylase had no effect on hepatic receptordependent LDL uptake in animals maintained on a very-lowcholesterol, low-fat diet. As shown at the bottom of Fig. 4, the reduction in LDL cholesterol observed in animals infected with AdCMV7 $\alpha$ was entirely the result of reduced total LDL cholesterol transport (from 173 to $94 \mu \mathrm{g} / \mathrm{h}$ per 100 grams of body weight). The rates of hepatic receptor-dependent LDL uptake and total LDL cholesterol transport in two hamsters administered $1 \times 10^{10} \mathrm{pfu}$ of control virus (AdCMVLuc) were not different from the uninfected control animals (data not shown).

Cholesterol in the endoplasmic reticulum is the substrate for hepatic $7 \alpha$-hydroxylase. An increase in hepatic $7 \alpha$-hydroxylase activity, by diverting cholesterol from this pool into the bile acid biosynthetic pathway, would be expected to derepress HMG CoA reductase expression, and, as a consequence, increase hepatic cholesterol synthesis. To determine if primary overexpression of hepatic $7 \alpha$-hydroxylase results in upregulation of de novo cholesterol synthesis, rates of hepatic cholesterol 


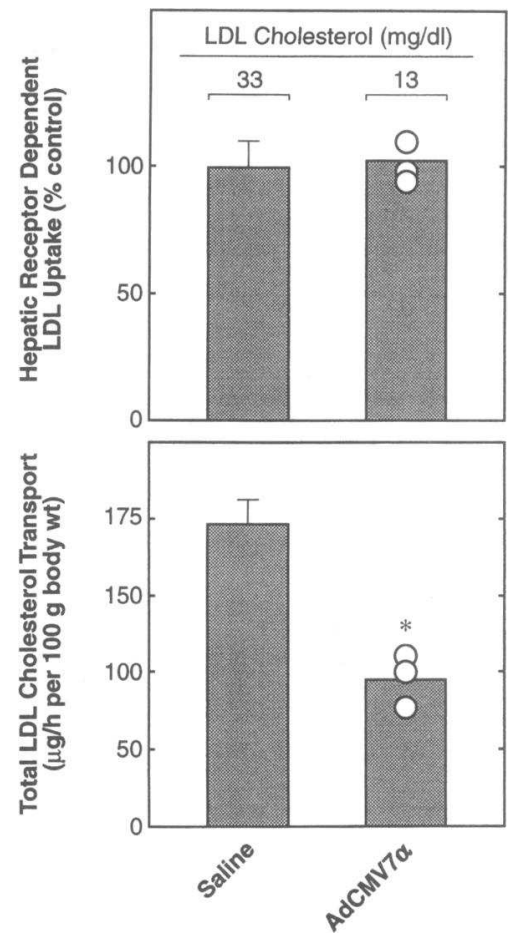

Figure 4. Effect of $7 \alpha$ hydroxylase gene transfer on the rates of hepatic receptor-dependent LDL uptake and LDL cholesterol entry into plasma (total LDL cholesterol transport). Hepatic receptor-dependent LDL uptake and total LDL cholesterol transport were determined $3 \mathrm{~d}$ after the intravenous injection of $1 \times 10^{10}$ pfu AdCMV7 $\alpha$ or an equal volume of saline. Data in the control group represent the mean \pm 1 SD for six animals. Individual values for the AdCMV7a animals are shown as open circles and the mean value as a bar. * Significantly differs from the saline control group, $P<0.05$.
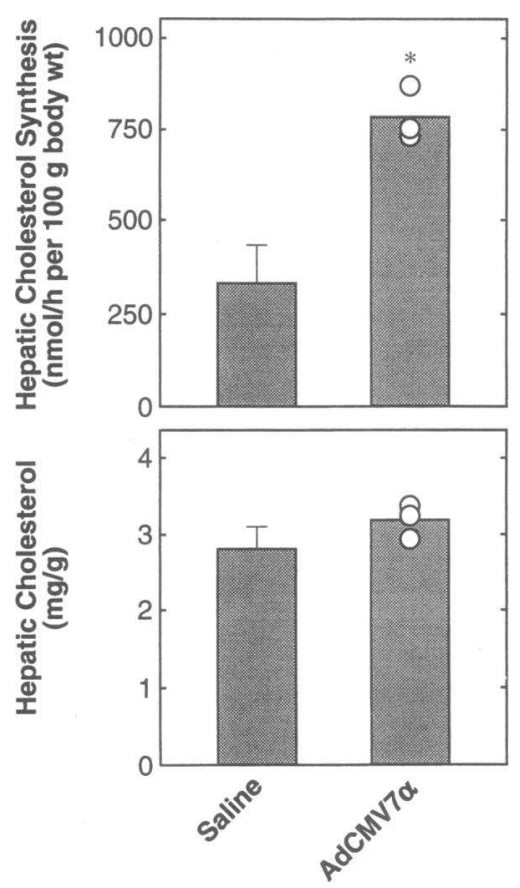

Figure 5. Effect of $7 \alpha$ hydroxylase gene transfer on the rate of hepatic cholesterol synthesis and the cholesterol content of the liver. Rates of hepatic cholesterol synthesis were quantified in vivo using $\left[{ }^{3} \mathrm{H}\right]$ water $3 \mathrm{~d}$ after the intravenous injection of $1 \times 10^{10}$ pfu Ad$\mathrm{CMV} 7 \alpha$ or an equal volume of saline. Hepatic total cholesterol content was determined as described in Methods. Data in the control group represent the mean \pm 1 SD for six animals. Individual values for the AdCMV7 $\alpha$ animals are shown as open circles and the mean value as a bar. * Significantly differs from the saline control group, $P<0.05$.

synthesis were measured in vivo $3 \mathrm{~d}$ after the administration of $1 \times 10^{10}$ pfu AdCMV7 $\alpha$. Plasma cholesterol concentrations declined by $\sim 50 \%$ in these hamsters. As shown in Fig. 5, rates of hepatic cholesterol synthesis in AdCMV7 $\alpha$-infected animals were $\sim 2.5$-fold greater than in uninfected animals. Rates of hepatic cholesterol synthesis in four hamsters treated with 1 $\times 10^{10} \mathrm{pfu}$ of control virus (AdCMVLuc or AdCMV $\beta$ gal) were slightly higher $(31 \%)$ than the mean of the uninfected control animals - a difference that did not achieve statistical significance (data not shown). Consistent with the effect of overexpression of $7 \alpha$-hydroxylase on hepatic cholesterol synthesis, HMG CoA reductase mRNA levels were increased in the livers of AdCMV7 $\alpha$-infected animals when compared with animals infected with a control virus (as illustrated in Fig. 1). As also shown in Fig. 5, overexpression of hepatic $7 \alpha$-hydroxylase had no effect on the total cholesterol content of the liver in animals maintained on a very-low-cholesterol, low-fat diet. Similarly, the cholesterol content of hepatic microsomes was not reduced in AdCMV7 $\alpha$-infected animals.

Newly synthesized bile acids join a large enterohepatic pool of bile acids that circulates several times a day between the liver and intestine. To determine if primary overexpression of $7 \alpha$-hydroxylase alters the enterohepatic pool, the size and composition of the pool was determined $3 \mathrm{~d}$ after the administration of $1 \times 10^{10} \mathrm{pfu}$ AdCMV7 $\alpha$. As shown in Table I, transient overexpression of hepatic $7 \alpha$-hydroxylase led to expansion of the enterohepatic pool of bile acids by $53 \%$. In contrast, the bile acid sequestrant cholestyramine reduced the size of the enterohepatic pool (and prevented the increase in pool size caused by primary overexpression of $7 \alpha$-hydroxylase). As also shown in Table I, primary overexpression of $7 \alpha$-hydroxylase had no effect on the composition of the enterohepatic pool, suggesting that distal steps in the bile acid biosynthetic pathway were not rate limiting even under circumstances in which $7 \alpha$ hydroxylase was markedly overexpressed. As described previously, cholestyramine increased the proportion of cholic acid

in the enterohepatic pool at the expense of chenodeoxycholic acid (32).

These initial studies concerning the metabolic consequences of primary overexpression of $7 \alpha$-hydroxylase were carried out in animals fed a very-low-cholesterol, low-fat (chow) diet. Because the mechanisms regulating cholesterol homeostasis in the liver are sensitive to dietary cholesterol and triglyceride intake, additional experiments were conducted in animals maintained on a diet intended to simulate that of Western humans. For these experiments, the control diet was supplemented with triglyceride (10\% coconut oil and 5\% safflower oil by weight) and small amounts of cholesterol $(0.1 \%$ by weight $)$. Animals were maintained on this diet for $6 \mathrm{wk}$ at which time plasma cholesterol levels stabilized in the $300-350 \mathrm{mg} / \mathrm{dl}$ range with LDL cholesterol concentrations of $150-200 \mathrm{mg} / \mathrm{dl}$. Basal levels of $7 \alpha$-hydroxylase activity were $\sim 50 \%$ lower in animals fed the Western-type diet than in animals fed the low-fat control diet $(31 \pm 7$ vs. $66 \pm 17 \mathrm{pmol} / \mathrm{h}$ per $\mathrm{mg}$ ). The reduced basal level of $7 \alpha$-hydroxylase activity in animals maintained on the Western-type diet was apparently related to the high triglyceride content of the diet. Thus, supplementing the control diet with triglyceride alone also reduced $7 \alpha$-hydroxylase activity by $\sim 50 \%$, whereas supplementing the control diet with cholesterol alone had no significant effect (our unpublished observation). In any event, the fold increase in hepatic $7 \alpha$-hydroxylase activity produced by AdCMV7 $\alpha$ infection was greater in animals fed the Western-type diet than in animals maintained on the low-fat control diet (due to the lower basal level of activity in animals fed the Western-type diet). Animals maintained on the Western-type diet manifested an $\sim 20$-fold increase in hepatic $7 \alpha$-hydroxylase activity $(31 \pm 7$ to $644 \pm 119 \mathrm{pmol} / \mathrm{h}$ per $\mathrm{mg}$ ) and a dramatic reduction ( $333 \pm 28$ to $128 \pm 20 \mathrm{mg} / \mathrm{dl}$ ) in plasma cholesterol concentrations $3 \mathrm{~d}$ after the administration of 1 $\times 10^{10}$ pfu AdCMV7 $\alpha$. Fractionation of lipoproteins from plasma obtained from infected and uninfected animals maintained on the Western-type diet revealed that the decrease in total plasma cholesterol resulted largely from a reduction in the 


\begin{tabular}{|c|c|c|c|c|c|c|c|}
\hline & \multirow[b]{2}{*}{ Bile acid pool size } & \multicolumn{6}{|c|}{ Proportion of total bile acid pool (\%) } \\
\hline & & TCA & GCA & TCDA & GCDA & TDCA & GDCA \\
\hline \multicolumn{8}{|c|}{ ( $\mu$ moV100 gram of body wt) } \\
\hline Control & $15 \pm 2$ & $44 \pm 3$ & $38 \pm 3$ & $9 \pm 1$ & $4 \pm 1$ & $6 \pm 1$ & $2 \pm 1$ \\
\hline $\operatorname{AdCMV7} \alpha$ & $23 \pm 2 *$ & $44 \pm 2$ & $39 \pm 4$ & $9 \pm 2$ & $5 \pm 1$ & $4 \pm 1$ & $1 \pm 1$ \\
\hline Cholestyramine & $9 \pm 1^{*}$ & $60 \pm 7$ & $29 \pm 2$ & $3 \pm 1$ & $1 \pm 1$ & $5 \pm 1$ & $2 \pm 1$ \\
\hline AdCMV7 $\alpha+$ cholestyramine & $14 \pm 3$ & $62 \pm 8$ & $25 \pm 4$ & $5 \pm 1$ & $1 \pm 1$ & $6 \pm 1$ & $1 \pm 1$ \\
\hline
\end{tabular}

$T C A$, taurocholic acid; $G C A$, glycocholic acid; $T C D A$, taurochenodeoxycholic acid; GCDA, glycochenodeoxycholic acid; $T D C A$, taurodeoxycholic acid; $G D C A$, glycodeoxycholic acid. Each value represents the mean $\pm 1 \mathrm{SD}$ for data obtained in three animals. * Significantly differs from the control group, $P<0.05$.

LDL fraction, which was greatly increased in control animals maintained on the Western-type diet (Fig. 6). HDL cholesterol was reduced to a lesser degree by overexpression of $7 \alpha$-hydroxylase, whereas VLDL cholesterol was unaffected. Time course experiments demonstrated a progressive reduction in plasma cholesterol over a 3-d period after infection with AdCMV7 $\alpha$. Plasma cholesterol concentrations were $345 \pm 41 \mathrm{mg} / \mathrm{dl}$ before infection and fell to $220 \mathrm{mg} / \mathrm{dl}$ at $24 \mathrm{~h}, 140 \mathrm{mg} / \mathrm{dl}$ at $48 \mathrm{~h}$, and $108 \mathrm{mg} / \mathrm{dl}$ at $72 \mathrm{~h}$.

The effects of primary overexpression of $7 \alpha$-hydroxylase on hepatic receptor-dependent LDL uptake and the rate of LDL cholesterol entry into plasma (total LDL cholesterol transport) in animals maintained on the Western-type diet are summarized in Fig. 7. Changes in LDL transport in response to the Westerntype diet reflected a complex interaction between the triglyceride and cholesterol present in the diet. As described previously (33), supplementing the very-low-cholesterol, low-fat diet with triglyceride alone (Fig. 7, dashed bars) increased both the rate

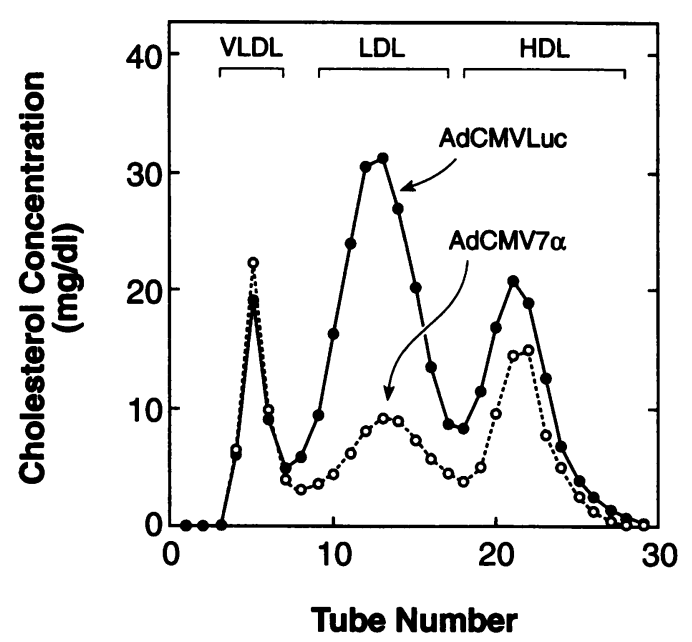

Figure 6. Effect of $7 \alpha$-hydroxylase gene transfer on the lipoprotein distribution of plasma cholesterol in hamsters maintained on a Westerntype diet. Animals were fed a diet enriched with triglyceride and cholesterol for $6 \mathrm{wk}$ as described in Methods. Plasma was obtained $3 \mathrm{~d}$ after the intravenous injection of $1 \times 10^{10}$ pfu AdCMV7 $\alpha$ or AdCMVLuc. Equal aliquots of plasma were pooled from three animals in each group. The pooled plasma was fractionated by Superose- 6 chromatography, and the eluted fractions were assayed for cholesterol. The retention times for hamster VLDL $(d<1.006$ grams/ml), LDL $(d=1.020-$ $1.055 \mathrm{grams} / \mathrm{ml})$, and HDL $(d=1.063-1.21 \mathrm{grams} / \mathrm{ml})$ are indicated. of LDL cholesterol entry into plasma (total LDL cholesterol transport) and the rate of receptor-dependent LDL uptake by the liver, resulting in little net change in plasma LDL cholesterol concentrations (mean $39 \mathrm{mg} / \mathrm{dl}$ vs. $30 \mathrm{mg} / \mathrm{dl}$ in controls). The addition of cholesterol to the triglyceride-enriched diet (Fig. 7, solid bars) further increased the rate of LDL cholesterol entry into plasma (total LDL cholesterol transport), but in addition suppressed hepatic receptor-dependent LDL uptake causing a large increase in plasma LDL cholesterol concentrations (to $181 \mathrm{mg} / \mathrm{dl}$ ). In animals maintained on the triglyceride and cholesterol supplemented (Western-type) diet, primary overexpression of $7 \alpha$-hydroxylase (Fig. 7 , shaded bars) reduced total LDL cholesterol transport and restored receptor-dependent LDL uptake by the liver. As a consequence, circulating LDL cholesterol concentrations were restored to essentially normal levels.

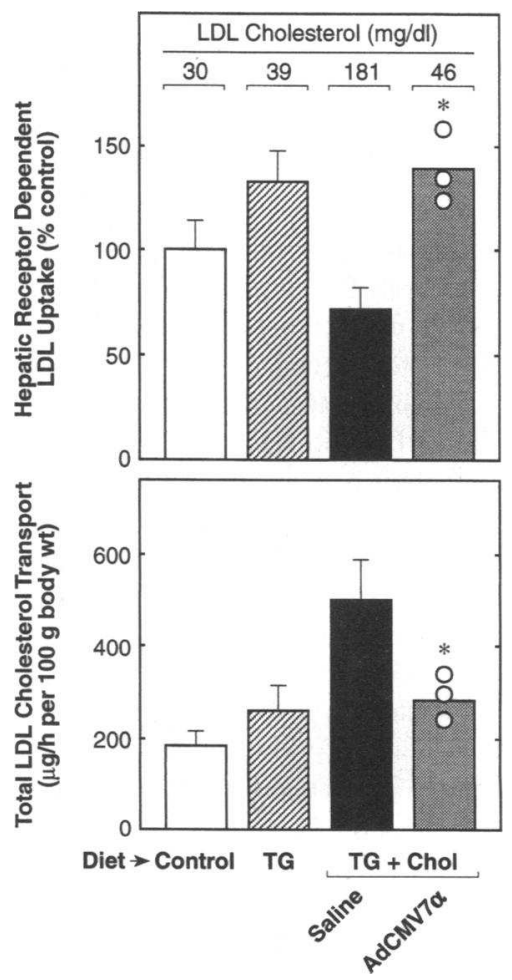

Figure 7. Effect of $7 \alpha-$ hydroxylase gene transfer on hepatic receptordependent LDL uptake and the rate of LDL cholesterol entry into plasma (total LDL cholesterol transport) in hamsters maintained on a Western-type diet. Animals were fed a very-low-fat, low-cholesterol (chow) diet, a diet enriched with triglyceride alone, or a diet enriched with triglyceride and cholesterol (Western-type diet) for 6 wk as described in Methods. Hepatic receptor-dependent LDL uptake and total LDL cholesterol transport were determined $3 \mathrm{~d}$ after the intravenous injection of 1 $\times 10^{10}$ pfu AdCMV $7 \alpha$ or an equal volume of saline. Data in the various control groups represent the mean \pm 1 SD for six animals. Individual values for the AdCMV7 $\alpha$ animals are shown as open circles and the mean value as a bar. ${ }^{*}$ Significantly differs from the saline control group, $P<0.05$. 


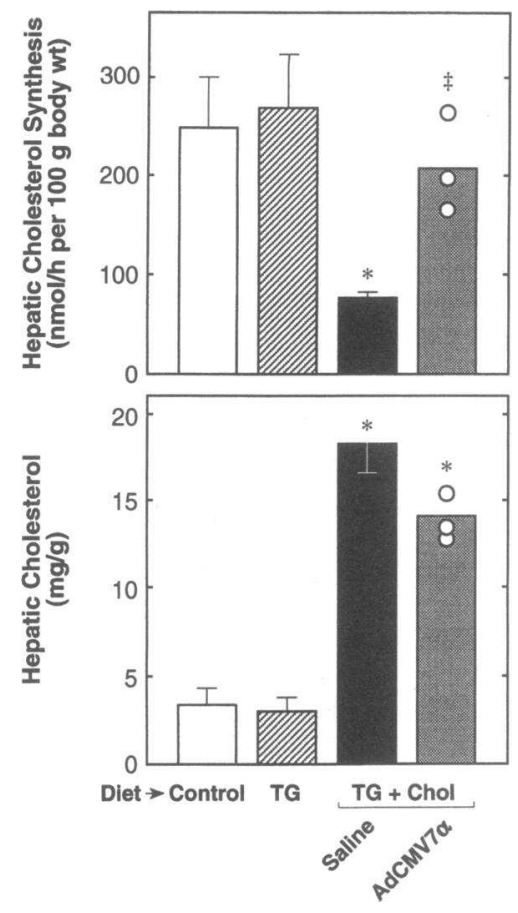

mals are shown differs from the saline control group, $P<0.05$.

In contrast, administration of $1 \times 10^{10} \mathrm{pfu}$ of control virus (AdCMVLuc or AdCMV $\beta$ gal) to four animals maintained on the Western-type diet had no effect on hepatic receptor-dependent LDL uptake, total LDL cholesterol transport, or plasma LDL cholesterol concentrations (data not shown).

In these experiments, changes in hepatic receptor-dependent LDL uptake paralleled changes in hepatic LDL receptor mRNA levels. Expression of mRNA encoding the LDL receptor was suppressed in the livers of animals fed the Western-type diet. $3 \mathrm{~d}$ after administration of AdCMV7 $\alpha$ to animals maintained on this diet, expression of LDL receptor mRNA was restored to levels similar to those observed in animals maintained on the very-low-cholesterol, low-fat control diet (data not shown). Thus, while primary overexpression of hepatic $7 \alpha$-hydroxylase did not upregulate the LDL receptor pathway in animals fed a very-low-cholesterol, low-fat diet, it did restore LDL receptor mRNA levels and hepatic receptor-dependent LDL uptake in animals fed a Western-type diet.

The effects of overexpression of $7 \alpha$-hydroxylase on the cholesterol content of the liver and the rate of cholesterol synthesis in animals maintained on a Western-type diet are shown in Fig. 8. The cholesterol content of the liver was much higher in animals maintained on the Western-type diet $(18 \mathrm{mg} / \mathrm{gram})$ than in animals maintained on the very-low-cholesterol, lowfat control diet $(3.2 \mathrm{mg} / \mathrm{gram})$. Consistent with the elevation in hepatic cholesterol stores, the rate of de novo cholesterol synthesis was suppressed by $\sim 70 \%$ in animals fed the Westerntype diet. $3 \mathrm{~d}$ after the administration of AdCMV7 $\alpha$ to animals maintained on this diet, hepatic cholesterol levels were insignificantly lower (14 vs. $18 \mathrm{mg} / \mathrm{gram}$ ). Despite the elevated hepatic cholesterol content, the rate of hepatic cholesterol synthesis returned to near normal levels $3 \mathrm{~d}$ after the administration of AdCMV7 $\alpha$.

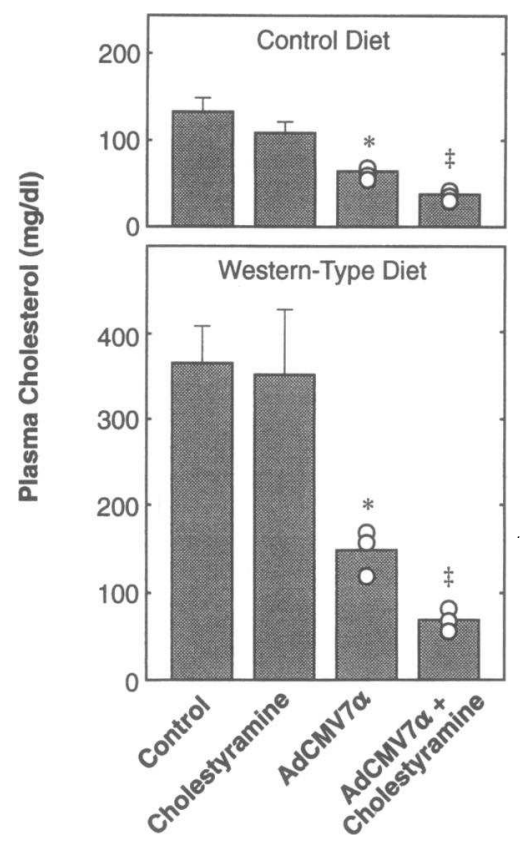

Figure 9. Effect of $7 \alpha$ hydroxylase gene transfer and cholestyramine on plasma cholesterol concentrations. Hamsters were maintained on control diet or a Westerntype diet for $6 \mathrm{wk}$. After intravenous administration of $1 \times 10^{10} \mathrm{pfu}$ AdCMV $7 \alpha$ to some animals, the hamsters were returned to their respective diets (with or without $1 \%$ cholestyramine) for an additional $3 \mathrm{~d}$, and plasma cholesterol concentrations were determined. Data in the control and cholestyramine groups represent the mean \pm 1 SD for six animals. Open circles indicate plasma cholesterol concentrations in indi-

vidual animals infected with $\operatorname{AdCMV7} \alpha$. The mean values are indicated by bars. * Significantly differs from the control group, $P<0.05$.

${ }^{\ddagger}$ Significantly differs from the AdCMV7 $\alpha$ group, $P<0.05$.

Primary overexpression of $7 \alpha$-hydroxylase was associated with expansion of the enterohepatic bile acid pool. Since expansion of the bile acid pool by oral administration of bile acids has been shown to enhance cholesterol absorption (34), a similar effect might limit the efficacy of primary overexpression of $7 \alpha$-hydroxylase in reducing plasma cholesterol levels. If so, administration of a bile acid sequestrant might be expected to enhance the hypocholesterolemic activity associated with transfer of a $7 \alpha$-hydroxylase gene. To investigate this possibility, we performed additional experiments in which animals maintained on control or Western-type diets were treated with AdCMV7 $\alpha$, cholestyramine, or both. In these studies, administration of AdCMV7 $\alpha$ increased hepatic $7 \alpha$-hydroxylase activity by $10-12$-fold in animals fed the control diet and by $20-25$ fold in animals maintained on the Western-type diet (due to the lower basal level of $7 \alpha$-hydroxylase activity in animals fed the Western-type diet). As expected, addition of $1 \%$ cholestyramine had no effect on hepatic mRNA levels for the transgene, which is expressed from a strong viral promoter not responsive to sterols, nor did cholestyramine significantly upregulate the (suppressed) levels of mRNA encoding native (hamster) $7 \alpha$ hydroxylase in animals greatly overexpressing the transgene (data not shown). As a consequence, the addition of cholestyramine did not further increase hepatic $7 \alpha$-hydroxylase activity above levels obtained after infection with AdCMV7 $\alpha$ alone. Nonetheless, cholestyramine reduced the size of the enterohepatic bile acid pool and augmented the cholesterol-lowering effects of AdCMV7 $\alpha$, as shown in Fig. 9. Thus, cholestyramine lowered plasma total and LDL cholesterol concentrations in animals infected with AdCMV7 $\alpha$, independent of any effects on hepatic $7 \alpha$-hydroxylase activity. One possible explanation for these observations is that expansion of the enterohepatic pool of bile acids in animals infected with AdCMV7 $\alpha$ resulted in enhanced cholesterol absorption-an effect prevented by cholestyramine. 


\section{Discussion}

These studies demonstrate that animals infected with recombinant adenovirus carrying a gene encoding cholesterol $7 \alpha$-hydroxylase transiently express the transgene at high levels in liver. Primary overexpression of hepatic $7 \alpha$-hydroxylase was associated with a dose-dependent increase in microsomal $7 \alpha$ hydroxylase activity, a reciprocal decline in plasma total and LDL cholesterol levels, and a more modest decline in HDL cholesterol. The marked reduction in plasma LDL cholesterol concentrations was attributable to a reduction in the rate of LDL cholesterol entry into plasma (total LDL cholesterol transport), and, in animals maintained on a Western-type diet, to restoration of receptor-dependent LDL uptake by the liver. The observation that primary overexpression of hepatic $7 \alpha$-hydroxylase is sufficient to substantially lower plasma cholesterol levels, even in the absence of interventions that interfere with the enterohepatic cycling of bile acids, suggests that $7 \alpha$-hydroxylase may be an attractive molecular target for strategies aimed at reducing cardiovascular risk. The magnitude of the hypocholesterolemic effect obtained after transient in vivo transfer of a cholesterol $7 \alpha-$ hydroxylase gene and the observation of additive effects of gene transfer and a bile acid sequestering resin suggest that genebased approaches might have efficacy complementary to conventional therapy, if sustained overexpression could be safely achieved.

More immediately, these studies provide some insights into the mechanisms regulating hepatic sterol balance and LDL transport. Our observations are consistent with prior work indicating that $7 \alpha$-hydroxylase activity is regulated primarily at the level of gene transcription $(5,8,35-39)$ and that bile acid(s) is (are) the principal regulatory effector(s) in the hamster (40). Hepatic $7 \alpha$-hydroxylase activity increased severalfold after AdCMV7 $\alpha$ infection and the enterohepatic pool of bile acids increased by $\sim 50 \%$. These changes were associated with suppression of endogenous $7 \alpha$-hydroxylase mRNA levels similar to that observed after expansion of the enterohepatic pool by oral administration of bile acids (10). Despite expansion of the bile acid pool and suppression of the endogenous gene, we observed roughly parallel increases in hepatic $7 \alpha$-hydroxylase mRNA content and enzyme activity in infected animals, suggesting that in the hamster under these experimental conditions $7 \boldsymbol{\alpha}$-hydroxylase activity is not substantially regulated by bile acids through posttranslational mechanisms. Unlike the rat, hamster $7 \alpha$-hydroxylase expression appears not to be regulated by cholesterol (substrate) availability (40).

The relationship between the level of hepatic $7 \alpha$-hydroxylase expression and circulating LDL concentrations is complex. In animals maintained on a very-low-cholesterol, low-fat diet, the decrease in plasma LDL cholesterol concentrations resulted entirely from a reduction in the rate of LDL cholesterol entry into plasma (total LDL cholesterol transport). Hepatic receptordependent LDL uptake and LDL receptor mRNA levels were not increased above levels observed in untreated control animals. How overexpression of $7 \alpha$-hydroxylase reduces the rate of LDL cholesterol entry into the plasma space is not known. LDL are formed in plasma during the metabolism of VLDL (41). VLDL, in turn, are triglyceride-rich particles secreted by the liver that function primarily to move triglyceride from the liver to peripheral sites of utilization and storage. After hydrolysis of VLDL triglyceride in extrahepatic tissues, the particle is either returned to the liver as a VLDL remnant or further metabolized to LDL. Thus, the rate of LDL formation is depen- dent on the proportion of VLDL that is converted into LDL as well as the rate of VLDL secretion. While we observed that plasma VLDL cholesterol concentrations were not altered by overexpression of $7 \alpha$-hydroxylase, the experiments described here do not discriminate between changes in VLDL secretion by the liver and changes in the fractional rate of conversion of VLDL to LDL.

The effect of AdCMV7 $\alpha$ on LDL transport was more impressive in animals maintained on a diet supplemented with triglyceride and small amounts of cholesterol. This diet raised plasma LDL cholesterol concentrations into the range commonly seen in Western humans $(150-200 \mathrm{mg} / \mathrm{dl})$. Elevated concentrations of LDL cholesterol in animals fed this Westerntype diet were due both to suppression of hepatic receptordependent LDL uptake and to a large increase in the rate of LDL cholesterol entry into plasma (total LDL cholesterol transport). Although the cholesterol content of individual LDL particles was modestly increased $(\sim 20 \%)$ in animals fed the Westerntype diet, most of the increase in total LDL cholesterol transport was due to an increase in the number of LDL particles entering the plasma space. Under these conditions, overexpression of $7 \alpha$-hydroxylase reduced total LDL cholesterol transport and restored hepatic receptor-dependent LDL uptake (and LDL receptor mRNA levels), thereby lowering LDL cholesterol levels by $\sim 75 \%$. Directionally similar, although smaller, effects on LDL transport have been observed when hepatic $7 \alpha$-hydroxylase expression was upregulated by dietary psyllium (10).

The precise mechanism whereby primary overexpression of $7 \alpha$-hydroxylase leads to induction of HMG CoA reductase and the LDL receptor pathway is not entirely clear. Presumably, accelerated conversion of cholesterol to bile acids causes depletion of a regulatory pool of unesterified cholesterol resulting in induction of sterol-regulated genes such as HMG CoA reductase and the LDL receptor $(42,43)$. In animals fed the control diet, overexpression of $7 \alpha$-hydroxylase increased the rate of hepatic cholesterol synthesis by nearly threefold but did not reduce hepatic total or esterified cholesterol or the unesterified cholesterol content of microsomes. Similarly, in animals maintained on the Western-type diet, overexpression of $7 \alpha$-hydroxylase completely reversed the suppressive effect of dietary cholesterol on HMG CoA reductase and the LDL receptor pathway despite the fact that microsomal unesterified cholesterol levels were not reduced and hepatic total and esterified cholesterol levels, although falling, were still markedly elevated. Several possibilities might account for these observations. First, it is likely that the regulatory pool of unesterified cholesterol is small relative to the large amount of structural cholesterol present in the cell, making any changes in the size of the regulatory pool difficult to detect. Secondly, in these transient overexpression experiments, a new steady state was likely not achieved by $3 \mathrm{~d}$, particularly in animals maintained on the cholesterol-enriched diet. It is possible, therefore, that the pool of hepatic unesterified sterol regulating HMG CoA reductase and the LDL receptor pathway is not in rapid equilibrium with the large pool of storage (esterified) cholesterol under these experimental conditions. Finally, the link between $7 \alpha$-hydroxylase and other sterol-regulated genes may be through a molecule other than cholesterol. For example, it has been suggested that overexpression of $7 \alpha-$ hydroxylase inactivates oxysterols that may be potent repressors of HMG CoA reductase and LDL receptor gene expression. In any case, our observations in vivo are consistent with recent studies in COS cells transfected with a cDNA encoding $7 \alpha$ hydroxylase, which showed that expression of $7 \alpha$-hydroxylase 
increased HMG CoA reductase activity without reducing cellular cholesterol levels (44), and with previous studies in Chinese hamster ovary cells where expression of $7 \alpha$-hydroxylase was associated with resistance of the LDL receptor to suppression by cholesterol (45).

Hepatic $7 \alpha$-hydroxylase is induced by interventions that deplete the bile acid pool (such as bile diversion, ileal resection, or administration of bile acid sequestrants) and suppressed by interventions that expand the pool (such as bile acid administration). Under these conditions, changes in $7 \alpha$-hydroxylase expression are always accompanied by parallel changes in HMG CoA reductase activity. The two enzymes would appear to be metabolically linked by cholesterol, which is the substrate for $7 \alpha$-hydroxylase and exerts tight feedback control on the expression of HMG CoA reductase. Nevertheless, it has been difficult to rule out the theoretical possibility that bile acids may directly inhibit HMG CoA reductase expression. In these studies, overexpression of an exogenous $7 \alpha$-hydroxylase gene resulted in expansion of the bile acid pool and suppression of endogenous $7 \alpha$-hydroxylase gene expression similar to that seen in hamsters fed large amounts of bile acids (10). Under these conditions, however, HMG CoA reductase mRNA and the rate of cholesterol synthesis were upregulated (rather than repressed as seen with bile acid feeding), strongly suggesting that bile acids exert little, if any, direct inhibitory effect on HMG CoA reductase.

Dietary cholesterol raises plasma total and LDL cholesterol concentrations; however, the response to a given intake of cholesterol varies enormously among different animal species and even among individuals of the same species (46). The liver plays a key role in adaptation to a high cholesterol diet since it is not only the recipient of absorbed dietary cholesterol but is also the major site through which cholesterol is eliminated from the body (2). In this regard, the level of expression of hepatic $7 \alpha$-hydroxylase appears to be a critical determinant of responsiveness to dietary cholesterol. On a low cholesterol diet, rapid conversion of cholesterol to bile acids necessitates a high rate of hepatic cholesterol synthesis to provide substrate. High basal rates of hepatic cholesterol synthesis, in turn, allow the liver to compensate for large inputs of dietary cholesterol simply by downregulating de novo synthesis. Hamsters express low basal levels of $7 \alpha$-hydroxylase and are more responsive to the cholesterolemic effects of dietary cholesterol than species such as rats and mice that exhibit far higher levels of basal $7 \alpha$ hydroxylase expression (40). In addition, hamster $7 \alpha$-hydroxylase is not significantly upregulated in response to dietary cholesterol (40), in contrast to the situation in species highly resistant to dietary cholesterol such as the rat and mouse. In the current studies, hepatic $7 \alpha$-hydroxylase activity in the hamster was raised (by primary overexpression) to levels ordinarily observed in rats and mice and produced resistance to dietary cholesterol similar to that of rats and mice. Available data sug gest that most humans resemble the hamster, with relatively low basal levels of hepatic bile acid and cholesterol synthesis and modest sensitivity to the cholesterolemic effects of dietary cholesterol $(2,46)$. These observations and those of the current study, that direct augmentation of hepatic $7 \alpha$-hydroxylase expression can restore hepatic LDL receptor activity and normalize serum cholesterol levels in hamsters fed a high-fat, highcholesterol diet, suggest that primary manipulation of $7 \alpha$-hydroxylase gene expression may have potential as a therapeutic target for the management of clinical hypercholesterolemia.

Inflammatory mediators (produced in response to infection or inflammatory disease) may induce disturbances in lipid and lipoprotein metabolism, and in the hamster endotoxin and various inflammatory mediators raise plasma total and LDL cholesterol concentrations $(47,48)$. In addition, these agents induce HMG CoA reductase expression and increase cholesterol synthesis rates in the liver. We did not examine the effect of adenovirus vectors on the release or levels of specific cytokines. Nevertheless, several lines of evidence suggest that the observed effects on sterol and lipoprotein metabolism were not nonspecific effects of viral infection or of the immune response to infection. First, the effects of AdCMV7 $\alpha$ were compared with control viruses expressing irrelevant genes (luciferase or $\beta$ galactosidase). Administration of these control viruses at the highest doses tended to raise serum LDL levels and increase the rate of hepatic cholesterol synthesis; however, both effects were small and statistically insignificant. In addition, overexpression of $7 \alpha$-hydroxylase markedly lowered serum LDL levels, whereas the dominant effect of the inflammatory mediators studied to date is, as noted above, to raise serum LDL concentrations in the hamster.

Like prior studies targeting expression of the LDL receptor (15-17) and apolipoprotein A-1 (14), this study demonstrates the utility of in vivo gene transfer as an experimental tool for physiologic studies of lipoprotein metabolism. In addition, because the biochemical effects of transient overexpression of cholesterol $7 \alpha$-hydroxylase are directionally ones which might exert a salutary effect on the development and/or progression of atherosclerosis, these experiments suggest one potential molecular target for gene-based therapeutic interventions to reduce cardiovascular risk. Before the potential of gene transfer to affect the course of atherosclerosis can be assessed, however, effective strategies to achieve sustained, high level expression of the transferred gene must be developed. The recent identification of host immune responses to expressed viral gene products as an important factor limiting the duration of foreign gene expression after adenovirus-mediated gene transfer, and the finding of sustained expression after transfer of a reporter gene into the livers of mice using a variant adenovirus vector carrying a ts mutation in the E2A region (49) suggest one potentially promising approach.

\section{Acknowledgments}

The authors thank Wendy Williams, Matthew Zimmerman, Jody Houston, and Anna Lorenc for excellent technical assistance, David Russell for the cDNA encoding rat cholesterol $7 \alpha$-hydroxylase, and Robert Gerard and R. Sanders Williams for helpful advice and constructive criticism.

This work was supported in part by grants HL-17669, Specialized Center for Research in Ischemic Heart Disease, HL-38049 and HL47551 from the National Heart, Lung and Blood Institute, a Grant-inAid from the American Heart Association (92008850), and a Texas Advanced Technology Program grant (003660-20).

\section{References}

1. Consensus Conference. 1985. Lowering blood cholesterol to prevent heart disease. JAMA (J. Am. Med. Assoc.). 253:2080-2086.

2. Dietschy, J. M. S. D. Turley, and D. K. Spady. 1993. Role of liver in the maintenance of cholesterol and low density lipoprotein homeostasis in different animal species, including man. J. Lipid Res. 34:1637-1659.

3. Shefer, S., S. Hauser, I. Berkersky, and E. H. Mosbach. 1970. Biochemica site of regulation of bile acid biosynthesis in the rat. J. Lipid Res. 11:404-411.

4. Myant, N. B., and K. A. Mitropoulos. 1977. Cholesterol $7 \alpha$-hydroxylase. J. Lipid Res. 18:135-153.

5. Russell, D. W., and K. D. R. Setchell. 1992. Bile acid biosynthesis. Biochemistry. 31:4737-4749. 
6. Danielsson, H., K. Einarsson, and G. Johansson. 1967. Effect of biliary drainage on individual reactions in the conversion of cholesterol to taurocholic acid. Eur. J. Biochem. 2:44-49.

7. Reihner, E., B. Angelin, M. Rudling, S. Ewerth, I. Bjorkhem, and K. Einarsson. 1990. Regulation of hepatic cholesterol metabolism in humans: stimulatory effects of cholestyramine on HMG-CoA reductase activity and low density lipoprotein receptor expression in gallstone patients. J. Lipid Res. 31:2219-2226.

8. Pandak, W. M., Y. C. Li, J. Y. Chiang, E. J. Studer, E. C. Gurley, D. M Heuman, Z. R. Vlahcevic, and P. B. Hylemon. 1991. Regulation of cholesterol 7 alpha-hydroxylase mRNA and transcriptional activity by taurocholate and cholesterol in the chronic biliary diverted rat. J. Biol. Chem. 266:3416-3421.

9. Suckling, K. E., G. M. Benson, B. Bond, A. Gee, A. Glen, C. Haynes, and B. Jackson. 1991. Cholesterol lowering and bile acid excretion in the hamster with cholestyramine treatment. Atherosclerosis. 89:183-190.

10. Horton, J. D., J. A. Cuthbert, and D. K. Spady. 1994. Regulation of hepatic $7 \alpha$-hydroxylase expression by dietary psyllium in the hamster. J. Clin. Invest. 93:2084-2092.

11. Miettinen, T. A. 1979. Effects of neomycin alone and in combination with cholestyramine on serum cholesterol and fecal steroids in hypercholesterolemic subjects. $J$. Clin. Invest. 64:1485-1493.

12. Probstfield, J. L., and B. M. Rifkind. 1991. The lipid research clinics coronary primary prevention trial: design, results, and implications. Eur. J. Clin. Pharmacol. 40(Suppl. 1):S69-S75.

13. Buchwald, H. R Varco, J. Matts, J. Long, L. Fitch, G. Campbell, M. Pearce, A. Yellin, W. Edmiston, R. Smink, et al. 1990. Effect of partial ileal bypass surgery on mortality and morbidity from coronary heart disease in patients with hypercholesterolemia. N. Engl. J. Med. 323:946-955.

14. Kopfler, W. P., M. N. Willard, T. Betz, J. E. Willard, R. D. Gerard, and R. S. Meidell. 1994. Adenovirus mediated transfer of a gene encoding human apolipoprotein A-I into normal mice increases circulating high density lipoprotein cholesterol. Circulation. 90:1319-1327.

15. Herz, J., and R. D. Gerard. 1993. Adenovinus-mediated transfer of low density lipoprotein receptor gene acutely accelerates cholesterol clearance in normal mice. Proc. Natl. Acad. Sci. USA. 90:2812-2816.

16. Ishibashi, S., M. S. Brown, J. L. Goldstein, R. D. Gerard, R. E. Hammer, and J. Herz. 1993. Hypercholesterolemia in low density lipoprotein receptor knockout mice and its reversal by adenovirus-mediated gene delivery. J. Clin. Invest. 92:883-893.

17. Kozarsky, K. F. D. R. McKinley, L. L. Austin, S. E. Raper, L. D. StratfordPerricaudet, and J. M. Wilson. 1993. In vivo correction of low density lipoprotein receptor deficiency in the Watanabe heritable hyperlipidemic rabbit with recombinant adenovirus. J. Biol. Chem. 269:13695-13702.

18. Gomez-Foix, A. M., W. S. Coats, S. Baque, T. Alam, R. D. Gerard, and C. B. Newgard. 1992. Adenovirus-mediated transfer of the muscle glycogen phosphorylase gene into hepatocytes confers altered regulation of glycogen metabolism. J. Biol. Chem. 267:25129-25134.

19. Graham, F. L., J. Smiley, W. C. Russell, and R. Nairn. 1977. Characteristics of a human cell line transformed by human adenovirus type 5. J. Gen. Virol. 36:59-74.

20. Alcom, J. L., E. Gao, Q. Chen, M. E. Smith, R. D. Gerard, and C. R. Mendelson. 1993. Genomic elements involved in transcriptional regulation of the rabbit surfactant protein-A gene. Mol. Endocrinol. 7:1072-1085.

21. Willard, J. E., C. Landau, D. B. Glamann, D. Burns, M. E. Jessen, M. J. Pirwitz, R. D. Gerard, and R. S. Meidell. 1994. Genetic modification of the vessel wall: comparison of surgical and catheter-based techniques for delivery of recombinant adenovirus. Circulation. 89:2190-2197.

22. Chiang, J. Y. L. 1991. Reversed-phase high-performance liquid chromatography assay of cholesterol $7 \alpha$-hydroxylase. Methods Enzymol. 206:483-491.

23. Glass, C. K., R. C. Pittman, G. A. Keller, and D. Steinberg. 1983. Tissue sites of degradation of apoprotein A-I in the rat. J. Biol. Chem. 258:7161-7167.

24. Mahley, R. W., K. H. Weisgraber, G. W. Melchior, T. L. Innerarity, and K. S. Holcombe. 1980. Inhibition of receptor-mediated clearance of lysine and arginine-modified lipoproteins from the plasma of rats and monkeys. Proc. Natl. Acad. Sci. USA. 77:225-229.

25. Spady, D. K., J. B. Meddings, and J. M. Dietschy. 1986. Kinetic constants for receptor-dependent and receptor-independent low density lipoprotein transport in the tissues of the rat and hamster. J. Clin. Invest. 77:1474-1481.

26. Spady, D. K., and J. M. Dietschy. 1983. Sterol synthesis in vivo in 18 tissues of the squirrel monkey, guinea pig, rabbit, hamster, and rat. J. Lipid Res. 24:303-315.
27. Williams, D. L., T. C. Newman, G. S. Shelness, and D. A. Gordon. 1986. Measurement of apolipoprotein mRNA by DNA-excess solution hybridization with single-stranded probes. Methods Enzymol. 128:671-689.

28. Horton, J. D., J. A. Cuthbert, and D. K. Spady. 1993. Dietary fatty acids regulate hepatic low density lipoprotein (LDL) transport by altering LDL receptor protein and mRNA levels. J. Clin. Invest. 92:743-749.

29. Chomczynski, P., and N. Sacchi. 1987. Single-step method of RNA isolation by acid guanidinium thiocyanate-phenol-chloroform extraction. Anal. Biochem. 162:156-159.

30. Spady, D. K., and J. A. Cuthbert. 1992. Regulation of hepatic stero metabolism in the rat. Parallel regulation of activity and mRNA for $7 \alpha$-hydroxylase but not 3-hydroxy-3-methylglutaryl-coenzyme A reductase or low density lipoprotein receptor. J. Biol. Chem. 267:5584-5591.

31. Scheffe, H. 1959. The Analysis of Variance. John Wiley \& Sons, New York. 192-202.

32. Turley, S. D., B. P. Daggy, and J. M. Dietschy. 1991. Cholesterol-lowering action of psyllium mucilloid in the hamster: sites and possible mechanisms of action. Metab. Clin. Exp. 40:1063-1073.

33. Spady, D. K., and J. M. Dietschy. 1988. Interaction of dietary cholesterol and triglycerides in the regulation of hepatic low density lipoprotein transport in the hamster. J. Clin. Invest. 81:300-309.

34. Cohen, B. I., R. F. Raicht, and E. H. Mosbach. 1977. Sterol metabolism studies in the rat. Effects of primary bile acids (sodium taurochenodeoxycholate and sodium taurocholate) on sterol metabolism. J. Lipid Res. 18:223-231.

35. Noshiro, M., M. Nishimoto, and K. Okuda. 1989. Rat liver cholesterol 7 $\alpha$-hydroxylase. J. Biol. Chem. 265:10036-10041.

36. Jones, M. P., W. M. Pandak, D. M. Hueman, J. Y. L. Chiang, P. B Hylemon, and A. R. Vlahcevic. 1993. Cholesterol $7 \alpha$-hydroxylase: evidence for transcriptional regulation by cholesterol or metabolic products of cholesterol in the rat. J. Lipid Res. 34:885-892.

37. Lavery, D. J., and U. Schibler. 1993. Circadian transcription of the $7 \alpha$ hydroxylase gene may involve the liver-enriched bZIP protein DBP. Genes \& Dev. 7:1871-1884.

38. Hoekman, M. F. M., M. J. Rientjes, J. Twisk, R. J. Planta, H. M. G. Princen, and W. H. Mager. 1993. Transcriptional regulation of the gene encoding cholesterol $7 \alpha$-hydroxylase in the rat. Gene (Amst.). 130:217-223.

39. Ramirez, M. I., D. Karaoglu, D. Haro, C. Barillas, R. Bashirzadeh, and G. Gil. 1994. Cholesterol and bile acids regulate cholesterol $7 \alpha$-hydroxylase expression at the transcriptional level in culture and in transgenic mice. Mol. Cell. Biol. 14:2809-2821.

40. Horton, J. D., J. A. Cuthbert, and D. K. Spady. 1995. Regulation of hepatic $7 \alpha$-hydroxylase expression and response to dietary cholesterol in the rat and hamster. J. Biol. Chem. 270:5381-5387.

41. Havel, R. J. 1984. The formation of LDL: mechanisms and regulation. $J$. Lipid Res. 25:1570-1576.

42. Brown, M. S., and J. L. Goldstein. 1986. A receptor-mediated pathway for cholesterol homeostasis. Science (Wash. DC). 232:34-47.

43. Goldstein, J. L., and M. S. Brown. 1990. Regulation of the mevalonate pathway. Nature (Lond.). 343:425-430.

44. Sudjana-Sugiaman, E., G. Eggertsen, P. Sjoblom, Y.-R. Maeda, M. Rudling, K.-I. Okuda, and I. Bjorkhem. 1994. Presence of cholesterol $7 \alpha$-hydroxylase enzyme protein in COS-cells leads to increased HMG CoA reductase activity. Biochem. Biophys. Res. Commun. 202:896-901.

45. Dueland, S., J. D. Trawick, M. S. Nenseter, A. A. MacPhee, and R. A. Davis. 1992. Expression of $7 \alpha$-hydroxylase in non-hepatic cells results in liver phenotypic resistance of the low density lipoprotein receptor to cholesterol repression. J. Biol. Chem. 267:22695-22698.

46. Beynen, A. C., M. B. Katan, and L. F. M. Van Zutphen. 1987. Hypoand hyperresponders: individual differences in the response of serum cholesterol concentration to changes in diet. Adv. Lipid Res. 22:115-171.

47. Feingold, K. R., I. Hardardottir, R. Memon, E. J. T. Krul, A. H. Moser, J. M. Taylor, and C. Grunfeld. 1993. Effect of endotoxin on cholesterol biosynthesis and distribution in serum lipoproteins in Syrian hamsters. J. Lipid Res. 34:2147-2158

48. Grunfeld, C., and K. R. Feingold. 1992. Tumor necrosis factor, interleukin, and interferon induced changes in lipid metabolism as part of host defense. Proc. Soc. Exp. Biol. Med. 200:224-227.

49. Engelhardt, J. F., X. Ye, B. Doranz, and J. M. Wilson. 1994. Ablation of E2A in recombinant adenoviruses improves transgene persistence and decreases inflammatory response in mouse liver. Proc. Natl. Acad. Sci. USA. 91:61966200 . 